\title{
OPTIMALISASI PENERAPAN MEDIASI PENAL SEBAGAI ALTERNATIF PENYELESAIAN PERKARA TINDAK PIDANA
}

\author{
Tendy Septiyo, Joko Setiyono, Muchlas Rastra Samara \\ Magister Ilmu Ilmu Hukum, Universitas Diponegoro \\ Jalan Imam Bardjo, S.H. No. 1-3, Kampus Undip Pleburan, Kota Semarang \\ Email: tendiseptiyo@gmail.com,Jokosetiyono1961@gmail.com, \\ muchlasmuksin02@gmail.com
}

\begin{abstract}
Abstrak
Beberapa pihak menilai bahwa penyelesaian perkara tindak pidana melalui sistem peradilan pidana dinilai kurang maksimal, maka dari itu melalui konsep mediasi penal dapat dioptimalisasikan menjadi alternatif dalam menyelesaikan perkara tindak pidana di luar pengadilan. Konsep mediasi penal diambil dari "restorative justice yang berusaha memeberikan keadilan dengan adanya keseimbangan antara korban dan pelaku tindak pidana". Permasalahan yang akan dibahas pada penelitian ini adalah bagaiaman upaya optimalisasi mediasi penal sebagai alternatif perkara tindak pidana di luar pengadilan, bagaimana kebijakan mediasi penal sebagai alternatif penyelesaian tindak pidana di masa mendatang. Permasalahan tersebut akan dianalisis dengan metode penelitian penelitian yuridis normatif, dengan pendekatan perundang-undangan, analisis. Berdasarkan hasil penelitian diketahui bahwa penyelesaian mediasi penal dilakukan di luar proses peradilan pidana melalui mekanisme perundingan/musyawarah selanjutnya dimintakan perdamaian guna menyelesaikan konflik. Kebijakan mediasi penal dalam pembaharuan hukum pidana bisa dilakukan melalui dua cara yaitu mediasi penal di luar proses peradilan pidana dan mediasi penal sebagai bagian dari proses sistem peradilan pidana.
\end{abstract}

Kata Kunci: Optimalisasi, Mediasi, Keadilan Restoratif.

\begin{abstract}
Absract
Some parties consider that the settlement of criminal cases through the criminal justice system is considered to be less than optimal, therefore through the concept of mediation, the penalties can be optimized as an alternative in resolving criminal cases outside the court. This concept is taken from restorative justice, which tries to provide justice with a balance between the victim and the perpetrator of a criminal act. The problems that will be discussed in this research are how to optimize penal mediation as an alternative to criminal cases outside the court, how to use penal mediation as an alternative to resolve future crimes. These problems will be analyzed using normative juridical research methods, with a statutory approach analysis. Based on the results of the research, it is known that the settlement of penal mediation is carried out outside the criminal justice process through a negotiation/deliberation mechanism and then is asked for peace to resolve the conflict. Penal mediation policy in criminal law reform can be carried out in
\end{abstract}


two ways, namely penal mediation outside the criminal justice process and penal mediation as part of the criminal justice system process.

Keywords : Optimization, Mediation Of Penalties, Restorative Justice.

\section{A. PENDAhuluan}

Kejahatan pada dasarnya adalah perbuatan yang dinilai sebagai suatu tindakan menyimpang ${ }^{1}$. Suatu tindak kejahatan dalam lingkup peradilan pidana wajib dipertanggungjawabkan oleh pelaku. Pada praktiknya jika korban kejahatan atas kehendaknya ingin mencabut laporan, namun tidak bisa dilakukan kejahatan tersebut merupakan delik biasa. Padahal dalam hukum pidana mengenal juga asas "ultimum remidium" yang artinya obat terakhir, atau penerapan hukum pidana dilakukan sebagai upaya terakhir. ${ }^{2}$ Dapat dikatakan bahwa penyelesaian melalui peradilan tidak selalu dapat memberikan keadilan dan tidak selalu mampu menyelesaikan masalah yang terjadi. Sangat diperlukan alternatif-alternatif lain ke arah penegakan hukum yang progresif dan responsif. Pemidanaan memang menjadi hal yang krusial, namun untuk kasus-kasus tertentu hal ini seharusnya dapat dialternatifkan. Salah satu alternatif penyelesaian kasus dalam perkara pidana yang dikenal saat ini adalah penerapan mediasi penal. ${ }^{3}$

Terlepas dari semua hal tujuan hukum, tujuan utama dari hukum adalah agar menciptakan ketertiban dilingkup masyarakat, disamping kepastian hukum karena

\footnotetext{
${ }^{1}$ Ismi Anandita, Erdianto, dan Rahmat Hendra, Penerapan Mediasi Penal dalam Penyelesaian Tindak Pidana Perkelahian Menurut Hukum Adat Kampar, JOM Fakultas Hukum, 3, No. 1 (2016): 3.

2 Afni Zahra, RB. Sularto, Penerapan Asas Ultimum Remedium Dalam Rangka Perlindungan Anak Pecandu Narkotika, Jurnal Law Reform, 13, No. 1, Hlm. 19.

3 Diah Ratna Sari Hariyanto., "MediasiPenal Dalam Ius Constitutum dan Ius Contituendum di Indonesia," KERTHA WICAKSANA: Sarana Komunikasi Dosen dan Mahasiswa 13, No. 1 (2019): 2637. Hlm. 27, doi: https://doi.org/10.22225/kw.13.1.920.26-37.
} 
ketertiban merupakan syarat utama untuk terciptanya masyarakat yang teratur dan berbudaya, hukum yang baik adalah hukum yang sesuai dengan hukum yang hidup (the living law) dalam masyarakat, yang tentu sesuai pula atau merupakan pencerminan dari nilai-nilai yang berlaku dalam masyarakat itu. ${ }^{4}$ Oleh karena itu, hukum dan masyarakat mempunyai hubungan yang sangat erat dan saling mempengaruhi, sehingga hukum sebagai pranata yang mengatur kehidupan manusia agar terciptanya ketertiban dalam pergaulan hidupnya, yang pada kenyataannya tidak bersifat otonom. Praktik penyelesaian perkara pidana bisa dilakukan melalui jalur litigasi dan non litigasi. Jalur non litigasi dibagi lagi menjadi dua bentuk yaitu Pertama, alternative to ajudikasi yang terdiri atas negosiasi dan mediasi; Kedua, alternative to litigasi yang terdiri atas negosiasi, mediasi dan arbitrase..$^{5}$

Praktik penyelesaian perkara di luar pengadilan selama ini memang tidak ada landasan hukum formalnya, sehingga sering terjadi suatu kasus yang secara informal telah ada penyelesaian damai (meskipun melalui mekanisme hukum adat), namun tetap saja diproses ke pengadilan sesuai hukum yang berlaku. ${ }^{6}$ Sehingga perlu adanya perubahan pemikiran tentang keadilan dalam hukum pidana. Sebuah fenomena yang sudah mendunia dewasa ini, masyarakat Internasional semakin menyadari dan menyetujui

\footnotetext{
${ }^{4}$ Elma Yanti., "Konsep Restorative Justice Melalui Mediasi Penal Dalam Penyelesaian Perkara Pidana Bermotif Ringan Pada Masyarakat Adat Kampung Kuala Gasib Di Kecamatan Koto Gasib Kabupaten Siak," Jurnal Hukum Das Sollen 1, No. 4 (2018): 2, doi: https://doi.org/10.32520/das-sollen.v1i4.333 .

${ }_{5}^{5}$ Abdul Halim Berkatullah, "Bentuk Perlindungan Hukum Bagi Konsumen Dalam Penyelesaian Sengketa Transaksi Elektronik Internasional Menurut UU No. 11 Tahun 2008,” Jurnal Hukum Bisnis 29, No. 1 (2010): 57.

${ }^{6}$ Barda Nawawi Arief, Mediasi Penal Penyelesaian Perkara diluar Pengadilan, Semarang: Pustaka Megister, 2008, Hlm. 3.
} 
bahwa perlu ada perubahan pola pikir yang radikal dalam menangani permasalahan pidana, di luar pengadilan. ${ }^{7}$

Mediasi penal adalah salah satu bentuk alternatif sengketa di luar pengadilan, yang biasa dikenal dengan istilah ADR (Alternative Dispute Resolution) memiliki konsep yang baik dalam menegakkan perlindungan hukum bagi korban. Dengan adanya mediasi penal, tuntutan-tuntutan yang diharapkan oleh korban dapat terlaksana sehingga kebermanfaatan bagi masyarakat dapat terwujud. Oleh karena itu, mediasi penal merupakan salah satu acces to justice yang dapat ditempuh oleh korban ataupun pelaku. ${ }^{8}$ Mediasi penal bisa dilakukan oleh pemuka masyarakat adat (ketua adat), berdasarkan tugas dan wewenang adat selaku pemegang kultur dari setiap daerah maka adat harus juga menjadi tempat pertama bagi resolusi damai. Ketua adat mempunyai otoritas untuk menyelesaikan baik kasus perdata maupun pidana. Keputusan adat dianggap mengikat pada pihak-pihak yang terlibat, namun putusan tersebut hanya menjadi pertimbangan bagi aparat hukum jika suatu sengketa diproses di sistem formal, ${ }^{9}$ sehingga perlu juga adanya instansi untuk mengatur dan mengawasi proses tersebut agar tidak terjadi kekacauan. ${ }^{10}$ Mediasi penal juga berkaitan dnegan "Acces to justice atau dalam bahasa Indonsia disebut Akses Menuju Keadilan adalah hak setiap orang untuk mendapatkan akses memperoleh keadilan yang merupakan hak asasi manusia. Penyelesaian melalui mediasi penal perlu digali lebih

\footnotetext{
${ }^{7}$ Surya Perdana, Riza Zarzani, dan Ahmad Fauzi, "Desain Model Peradilan Pidana Anak Berbasis Mediasi Penal," Kumpulan Penelitian Dan Pengabdian Dosen 1, No. 1 (2018): Hlm. 15.

${ }^{8}$ Muhammad Taufiq et al., "Mediasi Sebagai Penguatan Kearifan Lokal Banyumas Dalam Penyelesaian Perkara Pidana," Jurnal Media Hukum 24, No. 2 (2018): 139.

9 Trisno Raharjo, “Mediasi Pidana Dalam Ketentuan Hukum Pidana Adat, ” Jurnal Hukum Ius Quia Iustum 17, No. 3 (2010): 8, doi: https://doi.org/10.20885/iustum.vol17.iss3.art8.

${ }^{10}$ Satjipto Rahardjo, Membedah Hukum Progresif, Jakarta: Penerbit Buku Kompas, 2008, Hlm. 84.
} 
lanjut mengenai bentuk mediasi penal yang tepat untuk menyelesaikan perkara pidana sehingga aparat penegak hukum dapat memberikan peran dalam acces to justice secara maksimal untuk masyarakat". ${ }^{11}$

Berlandaskan pada uraian di atas, pada penelitian ini akan secara spesifik membahas permasalahan bagaimana upaya penerapan "mediasi penal sebagai alternatif penyelesaian perkara tindak pidana di luar pengadilan", kemudian bagaimana penerapan mediasi penal sebagai alternatif penyelesaian perkara tindak pidana saat ini, dan apa hambatan dalam implementasi mediasi penal di masa akan datang.

\section{B. METODE PENELITIAN}

Penelitian ini merupakan penelitan normatif yang menganalisis aturan tentang penerapan mediasi penal di indonesia. "Metode pendekatan yang diguanakan yaitu yuridis doktrinal, yang artinya berusaha meneliti hal-hal yang menyangkut hukum, baik formil mapun informil. Data penelitian yang digunakan adalah data sekunder sumber data sekunder yang terdiri dari bahan hukum primer, sekunder dan tersier". ${ }^{12}$ Metode pengumpulan data melalui studi kepustakaan selanjutnya dianalisis secara deskriptif analitis, hingga menyimpulkan hasil penelitian sesuai dengan permasalahan penelitian.

\section{PEMBAHASAN}

\section{Upaya Optimalisasi mediasi Penal Sebagai Alternatif Perkara Tindak Pidana Di}

\section{Luar Pengadilan}

\footnotetext{
${ }^{11}$ Cahya Wulandari, "Penyelesaian Perkara Pidana Melalui Mediasi Penal: Access To Justice Di Tingkat Kepolisian," Humani (Hukum dan Masyarakat Madani) 8, No. 1 (2018): 92, doi: http://dx.doi.org/10.26623/humani.v8i1.1389.

${ }^{12}$ Kornelius Benuf dan Muhamad Azhar, "Metodologi Penelitian Hukum Sebagai Instrumen Mengurai Permasalahan Hukum Kontemporer", Gema Keadilan 7, No. 1 (2020): 24.
} 
Mediasi merupakan suatu proses perdamaian yang dilakukan oleh para pihak yang bersengketa dan dibantu penyelesaiannya oleh seorang mediator demi tercapainya hasil akhir yang adil atau win-win solution, tanpa membuang biaya yang terlalu besar, akan tetapi tetap efektif dan diterima sepenuhnya oleh kedua belah pihak yang bersengketa secara sukarela. ${ }^{13}$ Konteks Tulisan ini akan khusus membahas mengenai Mediasi penal atau dalam istilah lain yaitu penal mediation juga disebut dengan istilah, yaitu mediation in criminal cases atau mediation in penal matters dalam istilah Belanda disebut strafbemiddeling, dalam istilah Jerman disebut Der Außergerichtliche Tataus-gleich (ATA) dan dalam istilah Perancis disebut de mediation pénale. Mediasi penal menghadirkan antara pelaku tindak pidana dan korban, maka mediasi penal ini sering juga disebut dengan istilah Victim-Offender Mediation (VOM), Täter-Opfer-Ausgleich (TOA), atau Offender-victim Arrangement (OVA). ${ }^{14}$

Mediasi penal sangat terkait dengan keadilan restorative, yang oleh Tony F. Marshall dirumuskan suatu definisi bahwa keadilan restoratif sebagai a process whereby parties with a stake in a specific collectively resolve how to deal with the aftermath of the offence and its implications for the future, artinya dalam mencapai keadilan restoratif parapihak yang berkepentingan wajib bersama-sama mencari cara untuk

\footnotetext{
${ }^{13}$ Suherman, "Upaya Mediasi Dalam Penyelesaian Sengketa Di Lembaga Perbankan", Jurnal Yuridis 4, No. 2 (2017): 182.

14 Barda Nawawi Arief, "Mediasi Penal Penyelesaian Perkara Pidana Di Luar Pengadilan," dari https://bardanawawi.wordpress.com/2009/12/27/mediasi-penal-penyelesaian-perkara-pidana-di-luarpengadilan/\# tn2. diakses (diakses pada 17 November 2019).
} 
tercapainya kesepakatan setelah terjadi suatu tindak pidana serta kesepakatan mengenai sikap yang akan ditempuh atas implikasinya di kemudian hari. ${ }^{15}$

Hal ini sejalan dengan yang dikemukankan oleh "Stuart M. Widman menyebut mediasi penal sebagai process whith a mediator facilitates communication and negotiation between parties to assist them in reaching a voluntary agreement regarding their dispute. Sama halnya M. William Baker, menyebutkan mediasi penal merupakan process of bringing victims and offender ti reach a mutual agreement regarding restitution would become the norm."16

Model berlakunya mediasi penal berdasarkan pemikiran Restorative Justice adalah sebuah model Victim-Offender Mediation dan Restorative Conference. Pada model Victim-Offender Mediation prinsipnya mempertemukan parapihak yang difasilitatori oleh mediator, selanjutnya pada model Restorative Conference terdapat pihak selain primary victim yang termasuk seconday victim (keluarga dan kerabat). Tujuannya yaitu mendukung para pelaku untuk bertanggung jawab dan pelaku kesempatan untuk mengatasi palanggaran atau kejahatan yang telah dilakukannya dan mendorong sebuah proses yang memberdayakan secara emosional sehingga tercapai tujuan akhir yang tidak merugikan. ${ }^{17}$

Mediasi penal ini dapat diterapkan dengan mengacu kepada ketentuan yang termuat dalam "Surat Edaran No. SE/8/VII/2018 tanggal 27 Juli 2018 tentang Penerapan

\footnotetext{
15 CSA Teddy Lesmana, "Mediasi Penal Sebagai Alternatif Penyelesaian Perkara Pidana Dalam Perspektif Pembaharuan Sistem Peradilan Pidana Indonesia, "Jurnal Rechten: Riset Hukum dan Hak Asasi Manusia 1, No. 1 (2019): 9-10.

${ }^{16}$ Usman dan Andi Najemi, "Mediasi Penal di Indonesia," Undang: Jurnal Hukum 1, No. 1 (2018): 68.

${ }^{17}$ Bambang Waluyo, Penegakan Hukum Di Indonesia, Jakarta: Sinar Grafika, 2015, Hlm. 166.
} 
Keadilan Restoratif (Restorative Justice) dalam Penyelesaian Perkara Pidana”, yaitu terhadap jenis tindak pidana yang terpenuhi syarat materilnya yaitu; tidak menimbulkan keresahan masyarakat dan tidak ada penolakan masyarakat, tidak berdampak konflik sosial, Adanya pernyataan dari semua pihak yang terlibat untuk tidak keberatan, dan melepaskan hak menuntutnya dihadapan hukum, prinsip pembatas; Pada pelaku: Tindak kesalahan pelaku relatif tidak berat, yakni kesalahan (schuld) atau mensrea dalam bentuk kesengajaan (dolus atau opzet) terutama kesengajaan sebagai maksud atau tujuan (opzet als oogmerk); dan Pelaku bukan residivis, dan Pada tindak pidana dalam proses: Penyelidikan; dan Penyidikan sebelum SPDP dikirim ke Penuntut Umum.

Selain syarat materil juga terdapat syarat formil sesuai dalam "Surat Edaran No. SE/8/VII/2018” tanggal 27 Juli 2018 tentang Penerapan Keadilan Restoratif (Restorative Justice) Dalam Penyelesaian Perkara Pidana, yaitu; "surat permohonan perdamaian kedua belah pihak (pelapor dan pelapor), Surat Pernyataan Perdamaian (akte dading) dan penyelesaian perselisiahan para pihak yang berperkara (pelapor dan/atau keluarga pelapor, terlapor dan/atau keluarga terlapor, dan perwakilan dari tokoh masyarakat) diketahui oleh atas penyidik, berita Acara Pemeriksaan tambahan pihak yang berperkara setelah dilakukan penyelesaian perkara melalui keadailan restoratif (restorative justice), Rekomendasi gelar perkara khusus yang menyetujui penyelesaian keadilan restoratif (restorative justice), Pelaku tidak keberatan atas tanggungjawab, ganti rugi, atau 
dilakukan dengan sukarela, Semua tindak pidana dapat dilakukan restorative justice terhadap kejahatan umum yang tidak menimbulkan korban manusia”. ${ }^{18}$

Mediasi penal merupakan refleksi nilai keseimbangan dari Pancasila agar tercapainya tujuan hidup berbangsa dan bernegara, yang diilandasi nilai religius, kekeluargaan dan keselarasan. Dengan adanya nilai-nilai Pancasila yang kita miliki, sungguh ironi bahwa setiap tindak pidana yang terjadi harus diselesaikan dengan pidana, karena pada hakikanya pidana bukanlah satu-satunya sarana untuk menyelesaikan masalah. "Secara historis, kultur masyarakat Indonesia menujunjung tinggi pendekatan konsesus. Hal ini tentu terkait dengan kearifan lokal hukum adat (local wisdom) merupakan nilai-nilai yang hidup dalam masyarakat (inner order/living law) Indonesia. Dari dimensi ini, mediasi penal dalam praktik dilakukan melalui mekanisme musyawarah lewat lembaga adat yang diatur dalam bentuk awig-awig, atau dalam peradilan adat misalnya peradilan adat Dayak". ${ }^{19}$ Sehingga pada tataran praktis hendaknya peradilan adat diatur sebagai salah satu cara atau solusi untuk melakukan mediasi penal sehingga membudayakan kearifan lokal di samping sistem peradilan pidana, agar eksistensi dan pengembangan ADR di Indonesia tampaknya lebih kuat dibandingkan dengan alasan ketidak efisienan proses dalam menangani sengketa.

\footnotetext{
${ }^{18}$ I. Putu Asti Hermawan Santosa, "Mediasi Penal sebagai Alternatif Penyelesaian Perkara Pidana bagi Perwujudan Keadilan Restoratif," Jurnal Hukum Positum 4, No. 1 (2019): 64-65, doi: https://doi.org/10.35706/positum.v4i1.3007.

${ }^{19}$ Yusriando, "Implementasi Mediasi Penal Sebagai Perwujudan Nila-nilai Pancasila Guna Mendukung Supremasi Hukum Dalam Rangka Pembangunan Nasional, ” Jurnal Pembaharuan Hukum 2, No. 1 (2015): 37, doi: http://dx.doi.org/10.26532/jph.v2i1.1413
} 
Berdasarkan hal tersebut, mediasi penal sebagai perwujudan nilai-nilai Pancasila mempunyai implikasi positif dan sangat diperlukan adanya undang-undang mediasi penal. Di Indonesia mediasi penal diatur secara terbatas dan parsial dalam Peraturan dan Surat Kapolri serta Peraturan Menteri. Belum adanya pengaturan tentang dasar hukum yang jelas dalam penerapan mediasi penal. $^{20}$ Pada tataran praktik, mediasi penal dilakukan lewat diskresi aparat penegak hukum, peradilan adat, yurisprudensi Mahkamah Agung dan putusan Pengadilan Negeri. Apabila undang-undang mediasi penal tidak dapat diwujudkan maka mengakibatkan penumpukan perkara terjadi di pengadilan sehingga secara ekonomis pengeluaran keuangan negara dan perekonomian negara meningkat. Undang-undang yang akan datang ini hendaknya diatur tentang mediasi penal yang dilakukan ditingkat penyidikan, penuntutan, pengadilan dan lembaga pemasyarakatan. Selain itu, juga diatur tentang eksistensi lembaga baru, petugas mediator, proses dan substansi mediasi penal. ${ }^{21}$

Mekanisme perkara secara non-litigasi atau ADR telah dilegitimasi melalui “Undang-Undang Nomor 30 Tahun 1999 tentang Arbitrase dan Alternatif Penyelesaian Sengketa dalam Pasal 1 ayat (10) yang menyatakan Alternatife Penyelesaian Sengketa adalah lembaga penyelesaian sengketa atau badan pendapat melalui prosedur yang

\footnotetext{
${ }^{20}$ Cacuk Sudarsono, "Pelaksanaan Mediasi Penal Dalam Penyelesaian Tindak Pidana Penganiayaan," Unnes Law Journal 4, No. 1 (2015): 22, doi: https://doi.org/10.15294/ulj.v4i1.7265.

${ }^{21}$ Lysa Angrayni, "Kebijakan Mediasi Penal Dalam Penyelesaian Perkara Tindak Pidana Ringan Perspektif Restorative Justice," Jurnal Hukum Respublica 16, No. 1 (2016): 43, doi: https://doi.org/10.31849/respublica.v16i1.1428.
} 
disepakati para pihak, yakni sengketa diluar pengadilan dengan cara konsultasi, negosiasi, mediasi, konsiliasi dan penilaian ahli”. ${ }^{22}$

Beberapa hal yang dapat dijadikan dasar dalam menentukan kebijakan menggunakan mediasi penal dalam penyelesaian perkara pidana, yaitu: Pertama, perlu memberikan rumusan yang tegas berkenaan dengan ketentuan mediasi penal”. Sehingga untuk ke depan, terhadap perkara tindak pidana ringan atau tindak pidana yang efek atau kerugian ekonomi maupun kerugian sosialnya relatif kecil atau tidak terlalu besar sudah memiliki payung hukum sebagaimana proses diversi yang diterapkan pada sistem peradilan anak. "Kedua, dalam menentukan kebijakan untuk memformulasi mediasi penal dalam sistem peradilan pidana di Indonesia, perlu ditentukam kriteria tindak pidana yang dapat diselesaikan melalui jalur mediasi penal. ${ }^{23}$

Prosedur penyelesaian sengketa di Indonesia diatur dalam "Pasal 1 angka 10 Nomor 30 Tahun 1999 tentang Arbitrase dan Alternatif Penyelesaian Sengketa, dinyatakan yang dimaksudkan dengan Alternatif Penyelesaian Sengketa adalah lembaga penyelesaian atau beda pendapat melalui prosedur yang disepakati para pihak, yakni penyelesaian di luar pengadilan dengan cara konsultasi, negoisasi, mediasi, konsiliasi, atau penilaian ahli", ${ }^{24}$ seperti yang disampaikan di atas, bahwa mediasi penal belum memiliki landasan hukum positif namun pada praktiknya telah terjadi pada hukum adat di berbagai daerah di Indonesia, seperti di Aceh dan Bali. Dengan local wisdom yang ada

\footnotetext{
${ }^{22}$ Ladin, "Penyelesaian Perkara Verzet Melalui Teknik Alternative Dispute Resolution," Jurnal Hukum Diversi 2, No. 2 (2016): 6-7, doi: https://doi.org/10.32503/diversi.v2i2.148.

${ }^{23}$ Yusriando, Op. cit., Hlm: 97-98

${ }^{24}$ I Wayan Rideng, "Penyelesaian Konflik Masyarakat Desa Pakraman Dalam Perpsektif Restorative Justice," Kertha Widya 1, No. 1 (2019): 143.
} 
mereka menempuh cara yang telah dimusyawarahkan guna menyelesaikan perkaraperkara yang terjadi di masyarakatnya. "Pada pasal 82 KUHP ayat 1" disebutkan bahwa "kewenangan menuntut pelanggaran yang diancam dengan denda saja, menjadi hapus, kalo dengan sukarela dibayar maksimum denda dan biaya-biaya yang telah dikeluarkan kalau penuntutan telah dimulai, atas kuasa pejabat yang ditunjuk untuk itu oleh aturan-aturan umum, dan dalam waktu yang ditetapkan olehnya”. Pasal ini menjadi titik yang bisa digunakan sebagai awal munculnya pasal-pasal yang lain berkait dengan mediasi penal. ${ }^{25}$

\section{Mediasi Penal Sebagai Alternatif Penyelesaian Perkara Tindak Pidana.}

Mediasi penal memiliki tujuan mulia dalam penyelesaian perkara pidana yang terjadi dalam masyarakat. Secara konseptual, dikatakan oleh "Stefanie Trankle dalam Barda Nawawi Arief, mediasi penal yang dikembangkan itu bertolak dari ide dan prinsip kerja (working principles)" sebagai berikut; Penanganan konflik (Conflict Handling/Konfliktbearbeitung): Tugas mediator adalah membuat para pihak melupakan kerangka hukum dan mendorong mereka terlibat dalam proses komunikasi. Hal ini didasarkan pada ide, bahwa kejahatan telah menimbulkan konflik interpersonal. Konflik itulah yang dituju oleh proses mediasi. Berorientasi pada proses (Process Orientation/Prozessorientierung): Mediasi penal lebih berorientasi pada kualitas proses daripada hasil, yaitu: menyadarkan pelaku tindak pidana akan kesalahannya, kebutuhankebutuhan konflik terpecahkan, ketenangan korban dari rasa takut, dan

\footnotetext{
${ }^{25}$ Imam Ali Bashori, "Mediasi Perspektif Hukum Islam (Studi Perma No. 1 Tahun 2008 Tentang Prosedur Mediasi Di Pengadilan)," Istinbath Jurnal Hukum 12, No. 2 (2017): 205-206.
} 
sebagainya. Proses informal (Informal Proceedings/Informalität): Mediasi penal merupakan suatu proses yang informal, tidak bersifat birokratis, menghindari prosedur hukum yang ketat. Ada partisipasi aktif dan otonom para pihak (Active and autonomous participation/Parteiautonomie/Subjek tivierung): Para pihak (pelaku dan korban) tidak dilihat sebagai objek dari prosedur hukum pidana, tetapi lebih sebagai subjek yang mempunyai tanggung jawab pribadi dan kemampuan untuk berbuat. Mereka diharapkan berbuat atas kehendaknya sendiri. ${ }^{26}$

Pada kenyataannya di Indonesia banyak hukum adat yang menjadi restorative justice, akan tetapi eksistensi hukum adat ini tidak diakui negara dalam hukum nasional. Munculnya ide restorative justice sebagai kritik atas penerapan sistem peradilan pidana dengan pemenjaraan yang dianggap tidak efektif menyelesaikan konflik dalam masyarakat Indonesia. ${ }^{27}$

Hambatan dari Kebijakan penanggulangan kejahatan melalui mediasi penal sebagai alternatif penyelesaian tindak pidana KDRT dalam penerapannya, diantaranya; belum melembaganya proses penyelesaian melalui mediasi ini di kalangan penegak hukum dan masyarakat, tidak adanya dasar hukum yang kuat dalam penyelesaian melalui mediasi ini menimbulkan aparat penegak hukum tidak berani melakukan diskresi, Sistem peradilan pidana berujung tombak pada proses penyidikan, apabila tersangka sudah dikenai penahanan pada proses penyidikan maka mau tidak mau akan berlanjut pada

\footnotetext{
${ }^{26}$ Hanafi Arief dan Ningrum Ambarsari, "Penerapan Prinsip Restorative Justice Dalam Sistem Peradilan Pidana Di Indonesia," Al Adl Jurnal Hukum 10, No. 2 (2018): 188, doi: http://dx.doi.org/10.31602/aladl.v10i2.1362.

27 Ibid. Hlm. 179.
} 
proses berikutnya yaitu penuntutan dan persidangan. Apabila tersangka sudah ditahan maka tidak ada pilihan lain bagi hakim untuk menjatuhkan pidana penjara, alhasil proses mediasi tidak bisa dilakukan, bagi pihak korban khususnya seorang isteri terkadang tidak mau dilakukan mediasi apalagi apabila sebelumnya sudah ada pria idaman lain, maka dengan adanya putusan pemidanaan akan mempermudah proses perceraian, Akibat atau dampak buruk dari tindak pidana kekerasan dalam rumah tangga cukup parah sehingga korban tidak bisa memaafkan, Para pihak tidak mentaati terhadap putusan mediasi, misalnya si terdakwa mengulangi tindak pidananya lagi, Ketidakpercayaan masyarakat terhadap aparat penegak hukum, sehingga apabila aparat penegak hukum menjadi mediator maka masyarakat atmemiliki persepsi negatif sehingga menimbulkan kecurigaan yang tidak beralasan. ${ }^{28}$

Kelebihan mediasi penal adalah pada umumnya pilihan penyelesaian diserahkan kepada pihak pelaku dan pihak korban. Selain itu mediasi penal berbiaya murah, sebagai pengganti sanksi pihak pelaku bisa menawarkan kompensasi atas dasar kesepakatan dengan pihak korban, sehingga aspek keadilan menjadi kesepakatan bersama antara pihak korban dan pihak pelaku, bukan berdasarkan perhitungan jaksa dan putusan hakim. Taufiqurrahman Abildanwa dalam artikelnya mengungkapkan bahwa upaya penyelesaian perkara pidana di luar proses peradilan merupakan proses penyelesaian perkara dengan cara kesepakatan oleh para pihak di luarkewenangan Pengadilan dengan

\footnotetext{
${ }^{28}$ Samsiar Arief dan Andi Rahmah, "Implementasi Mediasi Penal Dalam Penyelesaian Kasus Kekerasan Dalam Rumah Tangga (KDRT)," Petitum 6, No. 1 (2018): 17.
} 
realisasi pihak ketiga dengan memposisikan pelaku tindak pidana dengan korban dalam level yang sama. ${ }^{29}$

Berdasarkan KUHAP, kesepakatan damai melalui mediasi penal bukan salah satu syarat penghentian proses penyidikan, sebab berdasarkan Pasal 109 ayat (2) KUHAP, alasan penyidik menghentikan penyidikan, yaitu; tidak diperoleh cukup bukti, peristiwa yang disangkakan ternyata bukan merupakan tindak pidana, dan penghentian penyidikan demi hukum.

Hal yang perlu diperhatikan dalam penghentian perkara pada proses penyelidikan ataupun penyidikan yaitu mengenai pembagian delik biasa (gewone delic) dan delik aduan (klacht delik). Menurut Eddy O.S Hiariej, syarat ditentukannya suatu delik merupakan delik aduan harus secara eksplisit dinyatakan dalam pasal". ${ }^{30}$ Alasan penghentian proses perkara pidana terkait peniadaan penuntutan dan pengahapusan hak menuntut, berdasarkan Bab VIII Buku I KUHP tentang Hapusnya Kewenangan Menuntut Pidana dan Menjalankan Pidana, terdiri atas:

a. Pasal 77 , telah terdapat putusan hakim mengenai tindakan yang sama yang berkekuatan hukum tetap (in kracht)

b. Pasal 77, terdakwa meninggal dunia

c. Pasal 78, perkara tersebut telah daluwarsa,

\footnotetext{
${ }^{29}$ Taufiqurrohman Abildanwa, "Mediasi Penal Sebagai Upaya Dalam Rangka Pembaharuan Hukum Pidana Di Indonesia Berbasis Nilai-Nilai Keseimbangan,” Jurnal Pembaharuan Hukum 3, No. 1 (2016): 140, doi: http://dx.doi.org/10.26532/jph.v3i1.1353.

${ }^{30}$ Eddy O.S. Hiariej, Prinsip-Prinsip Hukum Pidana, Yogyakarta: Cahaya Atma Pustaka, 2015, Hlm. 145.
} 
d. Pasal 82, penyelesaian diluar persidangan dengan membayar denda maksimum untuk pelanggaran yang diancam dengan pidana denda. ${ }^{31}$

Langkah hukum yang biasa ditempuh oleh masyarakat untuk memperoleh keadilan (justice) dan kepastian hukum (legal certainty) atas sengketa yang sedang dihadapi adalah dengan memilih lembaga pengadilan. Pengadilan memiliki mekanisme tersendiri untuk memeriksa, mengadili dan memutus suatu perkara, yang harus dilalui oleh para pihak. Mekanisme tersebut ditentukan oleh peraturan perundang-undangan, sehingga urutan acara persidangan di pengadilan secara normatif adalah pasti dan baku, disamping itu, ketentuan Pasal 4 ayat (2) Undang-Undang Nomor 48 Tahun 2009 tentang Kekuasaan Kehakiman" telah memberikan jaminan bahwa "Pengadilan membantu pencari keadilan dan berusaha mengatasi segala hambatan dan rintangan untuk dapat tercapainya peradilan yang sederhana, cepat, dan biaya ringan". ${ }^{32}$

Kemudian di dalam KUHP banyak mengatur mengenai hak tersangka dan terdakwa, sementara pengaturan hak untuk korban (victim) tidak secara tegas dan tidak sebanyak hak bagi tersangka ataupun terdakwa. Hal tersebut dapat dimungkinkan hak korban dan masyarakat telah diwakilkan oleh negara. Berbeda halnya dengan pada masa

\footnotetext{
${ }^{31}$ I Ketut Sudira, Mediasi Penal Perkara Penelantaran Rumah Tangga, Yogyakarta: UII Press, 2016, Hlm. 25.

${ }^{32}$ Made Oka Cahyadi Wiguna, "Peluang Penyelesaian Sengketa Perdata Tentang Tanah Melalui Alternative Dispute Resolution Dengan Asas-Asas Hukum Perjanjian Di Dalamnya," Jurnal Hukum \& Pembangunan 48, no. 3 (2018): 3, doi: http://dx.doi.org/10.21143/jhp.vol48.no3.1743.
} 
lalu, dimana korban ataupun keluarganya dapat meminta langsung ganti rugi atau pembalasan kepada pelaku. ${ }^{33}$

\section{Kebijakan Mediasi Penal Sebagai Alternatif Penyelesaian Perkara Tindak Pidana Di Masa Akan Datang}

Sangat dibutuhkannya terobosan dalam sistem peradilan pidana untuk mengupayakan adanya mediasi penal dilatar belakangi dengan ide-ide pembaharuan hukum pidana (penal reform), dan masalah pragmatisme. Latar belakang ide penal reform tersebut antara lain mengenai "perlindungan korban, harmonisasi, restorative justice, mengatasi kekakuan/formalitas dalam sistem yang berlaku, menghindari efek negatif dari sistem peradilan pidana dan sistem pemidanaan yang ada saat ini, khususnya dalam mencari alternatif lain dari pidana penjara (alternative to imprisonment/alter-native to custody)", dan sebagainya.

"Kemudian hal yang melatar belakangi pragmatisme adalah dalam rangka mengurangi stagnasi atau penumpukan perkara ("the problems of court case overload"), untuk menyederhanakan proses peradilan dan sebagainya". ${ }^{34}$ Alternatif dalam sistem peradilan melalui mediasi penal sangat diperlukan, sebab:

a. diharapkan dapat mengurangi penumpukan perkara;

\footnotetext{
33 Bambang Waluyo, Viktimologi perlindungan Korban dan Saksi, Jakarta: Sinar Grafika Cetakan Keempat, 2016, Hlm. 2.

34 Beja Suryo Hadi Purnomo, "Kedudukan Mediasi Penal Dalam Sistem Peradilan Di Indonesia," Jurnal Ilmiah Ilmu Sosial 4, No. 2 (2018): 197, doi: http://dx.doi.org/10.23887/jiis.v4i2.16535.
} 
b. merupakan salah satu proses penyelesaian sengketa yang diangap lebih sederhana, cepat dan murah;

c. dapat memberikan akses seluas mungkin kepada para pihak yang bersengketa dalam rangka memperoleh keadilan; dan

d. memaksimalkan dan memperkuat fungsi lembaga pengadilan dan penyelesaian sengketa disamping proses penjatuhan pidana.

Kemudian berdasarkan rekomendasi "Dewan Komite Eropa Nomor R (99) 19 tentang Mediasi dalam Masalah Pidana", yang dirangkum menjadi sebuah "Explanatory Memorandum”. Bila rekomendasi tersebut di kaji, dianalisis, dan di jadikan alternatif ke dalam sistem peradilan pidana di Indonesia, maka rekomendasi tersebut memiliki beberapa arti dan model sebagai berikut.

a. Model "Informal Mediation". Model tersebut memiliki arti yaitu pelaksanaan penegakan hukum yang dilaksanakan oleh aparat penegak hukum dalam peradilan pidana dapat dikatakan sebagai criminal justice personel yang tugasnya dapat dilakukan oleh JPU (Jaksa Penuntut Umum) dengan memanggil para pihak untuk melakukan penyelesaian perkaranya dengan tujuan apabila terjadi kesepakatan antara para pihak, maka perkara tidak dilanjutkan ke tahap penuntutan. Kemudian dalam model mediasi penal tersebut dapat digunakan terhadap kasus-kasus yang informal. Model informal mediation tersebut dapat dilaksanakan oleh pekerja sosial atau pejabat pengawas yang dapat dikatakan sebagai probation officer, oleh pejabat polisi atau Hakim.

b. Model "Traditional village or tribal moots". Model mediasi penal tersebut dalam prosedurnya hampir sama seperti model penyelesaian perkara di dalam hukum adat, dimana seluruh masyarakat berkumpul dan berunding untuk memecahkan konflik kejahatan atau perkara yang terjadi diantara warganya. Model tersebut lazim dilaksanakan oleh negara yang kurang maju dan berada di wilayah pedesaan/pedalaman.

c. Model "Victim-offender mediation". Model tersebut lazim dan paling umum dilakukan atau dilaksanakan pada masyarakat luas. Prosedur alternatif mediasi penal tersebut dengan cara mempertemukan antara korban dan pelaku oleh 
mediator yang ditunjuk, namun, pihak-pihak yang terlibat tersebut berkaitan langsung dengan perkara pidana. Pihak yang berperan sebagai mediator dapat berasal dari pejabat formal, mediator independen, atau kombinasi yang memahami hukum. Mediasi tersebut dapat diadakan pada setiap tahapan proses, baik pada tahap kebijaksanaan polisi, tahap penuntutan, tahap pemidanaan atau setelah pemidanaan. Model tersebut diterapkan untuk semua tipe pelaku tindak pidana dan tipe tindak pidana tertentu (misalnya pengutilan, perampokan dan tindak kekerasan), selain itu diterapkan pada pelaku anak, pelaku pemula, namun ada juga untuk delik-delik yang berat. Pada model victim-offender mediation tersebut, mediator harus mengerti jalannya perkara dan bagaimana penyelesaian perkara yang dimediasikan berdasarkan saran, pendapat hukum dan ketentuan yang berlaku. Model tersebut dapat dikatakan sebagai model yang paling cocok untuk dilaksanakan di Indonesia jika mediasi penal menjadi aturan khusus dalam hukum pidana.

d. Model "Reparation negotiation programmes". Model tersebut memiliki prosedur dengan menilai atau memperkirakan kompensasi atau perbaikan yang harus dibayar oleh pelaku tindak pidana kepada korban. Hal yang menjadi titik utama di dalam model tersebut adalah kompensasi yang diberikan oleh pelaku tindak pidana terhadap korban untuk menciptakan keadilan yang merata. Pemberian kompensasi tersebut dilakukan pada saat pemeriksaan di pengadilan. Pemberiaan kompensasi tersebut berhubungan dengan rekonsiliasi antara para pihak, tetapi hanya berkaitan dengan perencanaan perbaikan materiel para pihak yang terlibat. Model reparation negotitation programmes tersebut menyatakan bahwa pelaku tidak pidana dapat dikenakan program kerja untuk dapat menyimpan uang agar dapat membayar ganti rugi/kompensasi terhadap korban tindak pidana sebagaimana program model ini diterapkan.

e. Model "Community panels of Courts". Model mediasi penal tersebut menitikberatkan terhadap perkara pidana yang dapat dikatakan bahwa suatu perkara pidana tersebut tidak harus diselesaikan dengan melewati penuntutan dalam badan peradilan pada prosedur penyelesaian perkara pidana di masyarakat. Model community panels of courts tersebut bertujuan untuk membuat penyelesaian dalam perkara pidana menjadi lebih fleksibel dan informal dengan melibatkan unsur mediasi atau negosiasi.

f. Model "Family and community group conferences". Model mediasi penal tersebut memiliki prosedur yang tidak hanya melibatkan korban dan pelaku tindak pidana saja di dalam jalannya mediasi, tetapi dapat melibatkan partisipasi masyarakat di dalam prosedur mediasi penal yang berlangsung. Masyarakat yang dimaksud tersebut adalah keluarga pelaku dan warga masyarakat lainnya, pejabat tertentu (seperti polisi dan hakim anak) dan para pendukung korban. Pelaku dan keluarganya diharapkan menghasilkan kesepakatan yang komprehensif dan memuaskan korban serta dapat membantu untuk menjaga pelaku keluar dari kesusahan/persoalan berikutnya. Model 
tersebut telah terbukti berhasil dan telah dikembangkan di Australia dan New Zealand. ${ }^{35}$

Jika di dalam tahapan pengadilan mediasi penal mencapai kesepakatan, maka hasilnya dapat digunakan sebagai alasan untuk menghapuskan menjalankan pidana bagi pelaku tindak pidana. Mediator pada tahap ini bisa dilakukan oleh hakim ataupun mediator dari luar pengadilan yang telah mendapatkan sertifikasi dan pelatihan. Mediasi tersebut adalah gabungan dari model Victim-Offender Mediation dan Reparation Negotiation Programmes. Pelaksanaan mediasi ini adalah sebagai berikut; Hakim dapat menawarkan mediasi penal sebagai alternatif penyelesaian perkara dengan perdamaian para pihak, jika para pihak menyetujui, maka diadakan persetujuan secara suka rela untuk mengikuti penyelesaian perkara dengan cara mediasi, Hakim dapat bertindak sebagai mediator ataupun dengan mediator di luar pengadilan yang telah memenuhi syarat dan bersertifikasi, mediasi penal dilakukan berdasarkan prinsip rahasia, jika mediasi tidak mencapai kesepakatan (gagal) maka proses pemeriksaan di muka pengadilan akan dilanjutkan sebagaimana mestinya. Sebaliknya jika berhasil, maka hasil kesepakatan yang dituangkan dalam akta kesepakatan menjadi berkekuatan tetap sebagaimana putusan pengadilan dan bersifat final, sehingga pelaku tidak dapat dituntut dan diadili kembali dalam proses peradilan pidana. ${ }^{36}$

\footnotetext{
${ }^{35}$ Reyner dan Dian Andriawan Daeng Tawang, "Alternatif Mediasi Penal Dalam Sistem Peradilan Pidana Di Indonesia," Jurnal Hukum Adigama 1, No. 2 (2018): 15-18, doi: http://dx.doi.org/10.24912/adigama.v1i2.2740.

${ }^{36} \mathrm{Ni}$ Kadek Ayu Ismadewi, Widodo T. Novianto dan Hartiwiningsih, "Mediasi Penal Dalam Penyelesaian Perkara Kekerasan Dalam Rumah Tangga," Jurnal Hukum Dan Pembangunan Ekonomi 5, No. 2 (2017): 175.
} 
Selain itu juga terdapat beberapa keunggulan dari penerapan mediasi penal di luar pengadilan, yaitu; untuk mengurangi kemacetan dan penumpukan perkara (court congestion) di lembaga peradilan, meningkatkan keterlibatan masyarakat (desentralisasi hukum) atau memberdayakan pihak yang bersengketa dalam proses penyelesaian sengketa, memperlancar jalur keadilan (acces to justice) di masyarakat, memberikan kesempatan bagi tercapainya penyelesaian sengketa yang menghasilkan keputusan yang dapat diterima oleh semua pihak, penyelesaian perkara lebih cepat dan biaya murah, bersifat tertutup/rahasia, lebih tinggi tingkat kemungkinan untuk melaksana kan kesepakatan, sehingga hubungan pihak-pihak bersengketa di masa depan masih dimungkinkan terjalin dengan baik, mengurangi merebaknya permainan kotor dalam lembaga peradilan. ${ }^{37}$

\section{PENUTUP}

Optimalisisasi media penal dapat dilakukan dengan di buatnya undang-undang tentang mediasi penal; dikeluarkannya peraturan Mahkamah Agung (Perma) untuk para hakim dalam segala tingkatannya menerapkan mediasi penal; dan pengaturan peradilan sebagai solusi untuk dapat melakukan mediasi penal sehingga membudayakan kearifan lokal di samping sistem peradilan pidana. Juga sebagai proses informal yang ditujukan kepada para pihak untuk mendiskusikan permasalahan-permasalahan mereka yang di bantu dengan pihak (mediator) sebagai pihak yang netral yang nantinya dapat

\footnotetext{
${ }^{37}$ Ludfi, Jumiati, dan Febriana Hidayati, "Mediasi Penal: Alternatiff Penyelesaian Perkara KDRTt," Jurnal Hukum Islam 18, No. 1 (2018): 23, doi: http://dx.doi.org/10.24014/hi.v18i1.6168.
} 
menyelesaikan permasalahan secara win-win solution di dalam proses pencarian alternative penyelesaian masalah yang mengutamakan keadilan dari pada kepastian hukum tidak lah mudah di mana banyaknya kendala di masyarakat dan sistem perundangundangan kita yang masih berfikiran dan berorientasi pada pemidanaan, bahwa orang yang melakukan tindak pidana harus di jatuhi hukuman pidana karena dilihat dari faktor substansi pemidanaan hanya terfokus pada faktor penjeraan semata.

\section{DAFTAR PUSTAKA}

\section{Buku :}

Arief, Barda Nawawi, Mediasi Penal: Penyelesaian Perkara di Luar Pengadilan, Semarang: Pustaka Magister, 2008

Hiariej, Eddy O.S, Prinsip-Prinsip Hukum Pidana, Yogyakarta, Cahaya Atma Pustaka, 2015.

Rahardjo, Satjipto, 2008. Membedah Hukum Progresif, Jakarta: Penerbit Buku Kompas.Sudira, I Ketut Mediasi Penal Perkara Penelantaran Rumah Tangga, Yogyakarta: UII Press, 2016.

Waluyo, Bambang, Penegakan Hukum Di Indonesia, Jakarta, Sinar Grafika, 2016.

, Viktimologi perlindungan Korban dan Saksi. Jakarta: Sinar Grafika Cetakan Keempat, 2016.

\section{Jurnal Ilmiah:}

Anandita, Ismi, Erdianto dan Rahmat Hendra, "Penerapan Mediasi Penal dalam Penyelesaian Tindak Pidana Perkelahian Menurut Hukum Adat Kampar”, JOM Fakultas Hukum, Vol 3 No. 1 2016, Riau: Fakultas Hukum Universitas Riau

Afni Zahra, RB. Sularto, Penerapan Asas Ultimum Remedium Dalam Rangka Perlindungan Anak Pecandu Narkotika, Jurnal Law Reform, 13, no. 1. 
Angrayni, Lysa, "Kebijakan Mediasi Penal Dalam Penyelesaian Perkara Tindak Pidana Ringan Perspektif Restroative Justice”, Jurnal Hukum Respublica, Vol. 16 No. 1 2016, Riau: Fakultas Hukum Universitas Lancang Kuning

Benuf, Kornelius, dan Muhamad Azhar, "Metodologi Penelitian Hukum Sebagai Instrumen Mengurai Permasalahan Hukum Kontemporer", Jurnal Gema Keadilan, Vol. 7 No. 1 2020, Semarang: Lembaga Pers Mahasiswa Fakultas Hukum Universitas Diponegoro

Suherman, "Upaya Mediasi Dalam Penyelesaian Sengketa Di Lembaga Perbankan", Jurnal Yuridis, Vol. 4 No. 2 2017, Jakarta: Fakultas Hukum Universitas Pembangunan Nasional "Veteran"

Sudarsono, Cacuk, "Pelaksanaan Mediasi Penal Dalam Penyelesaian Tindak Pidana Penganiayaan”, Unnes Law Journal, Vol. 4 No. 1 2015, Semarang: Fakultas Hukum Universitas Negeri Semarang

Ladin, "Penyelesaian Perkara Verzet Melalui Teknik Alternative Dispute Resolution", Journal Diversi, Vol. 2 No. 2 2016, Kediri: Fakultas Hukum Universitas Kadiri

Ludfi, Jumiati, dan Febriana Hidayati, "Mediasi Penal: Alternatif Penyelesaian Perkara KDRT”, Jurnal Hukum Islam, Vol. 18 No. 1 2018, Riau: Fakultas Syariah dan Hukum Universitas Islam Negeri Sultan Syarif Kasim

Wiguna, Made Oka Cahyadi, "Peluang Penyelesaian Sengketa Perdata Tentang Tanah Melalui Alternative Dispute Resolution Dengan Asas-Asas Hukum Perjanjian Di Dalamnya", Jurnal Hukum \& Pembangunan, Vol. 48 No.3 2018, Jakarta: Fakultas Hukum Universitas Indonesia

Yusriando, "Implementasi Mediasi Penal Sebagai Perwujudan Nila-nilai Pancasila Guna Mendukung Supremasi Hukum Dalam Rangka Pembangunan Nasional", Jurnal Pembaharuan Hukum, Vol. 2 No. 1 2015, Semarang: Fakultas Hukum Universitas Islam Sultan Agung

Lesmana, CSA Teddy, "Mediasi Penal Sebagai Alternatif Penyelesaian Perkara Pidana Dalam Perspektif Pembaharuan Sistem Peradilan Pidana Indonesia", Jurnal Rechten: Riset Hukum dan Hak Asasi Manusia, Vol.1 No. 1 2019, Sukabumi: Fakultas Hukum Universitas Nusa Putra

Arief, Samsiar dan Andi Rahmah, "Implementasi Mediasi Penal Dalam Penyelesaian Kasus Kekerasan Dalam Rumah Tangga (KDRT)", Petitum, Vol. 6 No. 1 2018, Makassar: Magister Hukum Universitas Indonesia Timur 
Yanti, Elma, "Konsep Restorative Justice Melalui Mediasi Penal Dalam Penyelesaian Perkara Pidana Bermotif Ringan Pada Masyarakat Adat Kampung Kuala Gasib Di Kecamatan Koto Gasib Kabupaten Siak", Jurnal Hukum Das Sollen, Vol. 1 No, 4 2018, Riau: Fakultas Hukum Universitas Islam Indragiri

Ismadewi, Ni Kadek Ayu dan Widodo T. Novianto, "Mediasi Penal Dalam Penyelesaian Perkara Kekerasan Dalam Rumah Tangga", Jurnal Hukum dan Pembangunan Ekonomi, Vol. 5 No. 2 2017, Surakarta: Fakultas Hukum Universitas Sebelas Maret

Abildanwa, Taufiqurrohman, "Mediasi Penal Sebagai Upaya Dalam Rangka Pembaharuan Hukum Pidana di Indonesia Berbasis Nilai-Nilai Keseimbangan”, Jurnal Pembaharuan Hukum, Vol. 3 No. 1 2016, Semarang: Fakultas Hukum Universitas Islam Sultan Agung

Purnomo, Beja Suryo Hadi, "Kedudukan Mediasi Penal Dalam Sistem Peradilan Di Indonesia", Jurnal Ilmiah Ilmu Sosial, Vol. 4 No. 2 2018, Bali: Fakultas Hukum dan Ilmu Sosial Universitas Pendidikan Ganesha

Usman dan Andi Najemi, "Mediasi Penal di Indonesia", Undang: Jurnal Hukum, Vol. 1 No. 1 2018, Jambi: Fakultas Hukum Universitas Jambi

Hariyanto, Diah Ratna Sari dan Pande Yogantara S, "Mediasi Penal Dalam Ius Constitutum dan Ius Contituendum di Indonesia", Kertha Wicaksana: Sarana Komunikasi Dosen dan Mahasiswa, Vol. 13 No. 1 2019, Bali: Fakultas Hukum Universitas Warmadewa

Reyner dan Dian Andriawan Daeng Tawang, "Alternatif Mediasi Penal Dalam Sistem Peradilan Pidana Di Indonesia", Jurnal Hukum Adigama, Vol. 1 No. 2 2018, Jakarta: Fakultas Hukum Universitas Tarumanagara

Wulandari, Cahya, "Penyelesaian Perkara Pidana Melalui Mediasi Penal: Access To Justice Di Tingkat Kepolisian", Humani (Hukum dan Masyarakat Madani), Vol. 8 No. 1 2018, Semarang: Fakultas Hukum Universitas Semarang

Perdana, Surya, Riza Zarzani, dan Ahmad Fauzi, "Desain Model Peradilan Pidana Anak Berbasis Mediasi Penal", Kumpulan Penelitian Dan Pengabdian Dosen, Vol. 1 No. 1 2018, Medan: Fakultas Hukum Universitas Muhammadiyah Sumatera Utara

Rideng, I Wayan, "Penyelesaian Konflik Masyarakat Desa Pakraman Dalam Perpsektif Restorative Justice", Kertha Widya, Vol. 1 No. 1 2019, Bali: Fakultas Hukum Universitas Panji Sakti

Bashori, Imam Ali, "Mediasi Perspektif Hukum Islam (Studi Perma No. 1 Tahun 2008 
Tentang Prosedur Mediasi Di Pengadilan)", Istinbath: Jurnal Hukum, Vol. 12 No. 2 2017, Lampung: Institut Agama Islam Negeri Metro

Arief, Hanafi dan Ningrum Ambarsari. "Penerapan Prinsip Restorative Justice Dalam Sistem Peradilan Pidana Di Indonesia", Al Adl: Jurnal Hukum, Vol. 10 No. 2 2018, Banjarmasin: Fakultas Hukum Universitas Islam Kalimantan Muhammad Arsyad Al-Banjari

Santosa, I Putu Asti Hermawan, "Mediasi Penal sebagai Alternatif Penyelesaian Perkara Pidana bagi Perwujudan Keadilan Restoratif”, Jurnal Hukum Positum, Vol. 4 No. 1 2019, Karawang: Fakultas Hukum Universitas Singaperbangsa Karawang

Taufiq, Muhammad, et al., "Mediasi Sebagai Penguatan Kearifan Lokal Banyumas Dalam Penyelesaian Perkara Pidana”, Media Hukum, Vol. 24 No. 2 2018, Yogyakarta: Fakultas Hukum Universitas Muhammadiyah

\section{Sumber lainnya:}

Barda Nawawi Arief, "Mediasi Penal: Penyelesaian Perkara Pidana Di Luar Pengadilan", https://bardanawawi.wordpress.com/2009/12/27/mediasi-penal-penyelesaianperkara-pidana-di-luar-pengadilan/\# tn2, diakses tanggal 10 Oktober 2020 